\title{
Examination of Local Online Course Characteristics Compared with MOOCs - A Case Study
}

\author{
Nissim Sabag ${ }^{1}$, David Pundak ${ }^{2} \&$ Elena Trotskovsky ${ }^{3}$ \\ ${ }^{1}$ Department of Electronic and Electrical Engineering, ORT Braude Academic College for Engineering, P.O. Box 78, \\ Karmiel, Israel \\ ${ }^{2}$ Web-Learning Unit, ORT Braude College, P.O. Box 78, Karmiel, Kinneret College, Israel \\ ${ }^{3}$ Department of Education and General Studies, ORT Braude Academic College for Engineering, P.O. Box 78, \\ Karmiel, Israel \\ Correspondence: Nissim Sabag, Department of Electronic and Electrical Engineering, ORT Braude Academic \\ College for Engineering, P.O. Box 78, Karmiel, Israel.
}

Received: April 20, 2017

doi:10.5430/irhe.v2n2p78
Accepted: May 23, 2017

Online Published: June 7, 2017

URL: https://doi.org/10.5430/irhe.v2n2p78

\begin{abstract}
During the past two years, we suggested to the college's engineering students to diversify their general studies with MOOCs. This experiment was awarded scant interest. The college students were then given the opportunity to enroll in a new online course in Hebrew, as part of the college's general studies. The current paper compares students' attitudes toward MOOC and the online college course. A qualitative method was used, including in-depth interviews, observations of the forum's activities and a students' opinion questionnaire. The participants were 25 students studied the online course, eight students completed MOOCs (from an engineering college), and 229 students from two colleges who did not study the online course or the MOOCs answered an opinion questionnaire about online courses. The completion of 25 students of the online course in comparison with the eight students who completed the MOOCs indicates a significant preference by the students for the online course over the MOOCs. The main criterion of the students to participate in the MOOCs was their interest in the subject matter, while the online course participants considered their own convenience first. The MOOC students reported a heavy learning load while the online course students reported a reasonable load.
\end{abstract}

Keywords: distance learning, learning evaluation, MOOC, online learning

\section{Introduction}

To comply with the policy of the Council of Higher Education in Israel, which requires every academic institute of engineering to include some general (non-engineering) studies as part of the engineering curriculum, an academic college of engineering included Massive Open Online Courses (MOOCs) as a replacement for one general studies course during the second semester of the academic year 2014 and the first semester of 2015 as a trial. Students had the opportunity to choose a MOOC run by a well-known university. An academic committee, appointed by the college, interviewed the students, examined the chosen MOOC's suitability to the college requirements, and then confirmed (or not) studying the course. The committee also followed up on the students' learning during their studies of the MOOCs and assessed the level of their learning. Upon completion of the MOOC assignments and the students' final presentations, the committee graded the work and approved the academic credits (author, 2014). About 15 students applied for the second semester of the academic year 2014. Seven of them were accepted and only five completed the MOOCs. An additional three students completed the MOOCs in the first semester of 2015. All the elected MOOCs are on the Coursera site. A list of the courses chosen by the students, the universities who created the courses and their length (in weeks) are detailed in Table 1 (the Financial Markets course was chosen by one student in the second semester of 2014 and one student in the first semester of 2015). 
Table 1. MOOC names, their length, and the universities who created them

\begin{tabular}{|c|c|c|c|}
\hline Course name & \multirow{2}{*}{\multicolumn{2}{|c|}{ University of Pittsburgh }} & Course length (weeks) \\
\hline A Look at Nuclear Science and Technology & & & 8 \\
\hline Introduction to Forensic Science & $\begin{array}{l}\text { University of } \\
\text { Glasgow }\end{array}$ & Strathclyde & 8 \\
\hline Introduction to International Criminal Law & $\begin{array}{l}\text { Case Western } \\
\text { University }\end{array}$ & Reserve & 8 \\
\hline Financial Markets & \multicolumn{2}{|l|}{ Yale University } & 8 \\
\hline Imagining Other Earths & \multicolumn{2}{|l|}{ Princeton University } & 12 \\
\hline $\begin{array}{l}\text { Water Supply and Sanitation Policy in Developing } \\
\text { Countries }\end{array}$ & \multicolumn{2}{|c|}{ University of Manchester } & 10 \\
\hline A beginner's guide to irrational behavior & \multicolumn{2}{|l|}{ Duke University } & 8 \\
\hline
\end{tabular}

The pedagogy in these courses relies on a mix of video lectures, reading materials, assignments that test understanding of the studied subject matter, and discussion groups that allow students to raise questions during the course. The video lectures are usually short, lasting 5-15 minutes, but there are also long lectures lasting up to an hour or more. In many cases, questions appear during the lectures to test the students' comprehension of the issues discussed in the lecture. Roughly, once a week, a large assignment is given to test deeper understanding of the studied subject matter. Learning in the MOOC courses relies on the assumption of learning towards mastery; in other words, the learners can go back over the studied materials and tests several times to improve their achievements in the weekly assignment.

The results of this stage of the research are detailed in (author, 2014). However, since the current paper presents the local online course characteristics in comparison to the MOOCs from the students' point of view, we briefly present some of the earlier findings.

\subsection{Reasons for the Choice of MOOC}

The main reason for the students' choice of the MOOCs was the interest stimulated by the course content and the opportunity to study a fascinating subject that was impossible to study within the framework of the college courses. This finding is in line with Sandeen's assertion that most MOOCs participants seem to be "testing the waters" by exploring subjects of interest to them (Sandeen, 2013).

Other reasons stemmed from the course lecturers' characteristics, their personalities, and the unique knowledge that they present.

Some of the students had prior knowledge of the subject of the chosen course and the course offered them supplementary and deeper knowledge of these subjects. An additional reason for their choice was the connection between the course and their hobby.

\subsection{Prior Knowledge Concerning the MOOC Content and Requirements}

The students registering for the courses had read the course syllabus, listened to an introductory lecture, considered the assignments that awaited them during the course, and assessed the weekly number of hours that they would have to invest to succeed in the course.

\subsection{Expectations from the Course}

The students noted various expectations from the course. One student had experience with MOOC and knew which difficulties and benefits could be anticipated. Some expected that they would attain deeper understanding of the studied subjects. Some saw the course as an opportunity to improve their English. Others wanted to communicate with students, in other locations in the world, on an interesting subject, or at least to open a window onto a new subject. Some of the students saw the course as an opportunity to reinforce their professional background. One student hoped that the course would help him advance the development of a start-up company.

Students expressed their expectations regarding the learning load in MOOCs before starting the course. At the end of the course, they were asked how much time they invested in MOOC learning. It seems that even though the students had quite a high estimation of the expected learning load in MOOC, they invested, on average, $45 \%$ more time than 
expected.

\subsection{Difficulties during Studies}

Some of the students encountered a very challenging experience such as a huge amount of learning material, and the extent of reading was up to 50 pages per lecture. The English was problematic including many professional terms. Some students report on the "lonely learner" effect. In those cases, the social communication with the other students at the MOOC was quite low. For others, the course was suitable.

\subsection{Advantages of the MOOCs}

All the students described the MOOC lecturers with appreciative words. All the students noted that their courses were thorough and interesting. Among the reasons for students' low participation in the MOOCs alternative were the need for a mastery of English and interacting with students from foreign cultures and languages.

The above insufficient participation of students in the MOOCs experiment drove the researchers of the current paper to start a second stage of the research in which a local online course on the History of Science, in Hebrew, which adopts the MOOC strengths and overcomes its weaknesses, was offered to the students. The research aimed to compare the students' impressions from MOOCs and local online course characteristics, investigating the difficulties involved in the learning process and learning load, and the level of interest in the course.

It was also interesting to learn other students' opinion (not only those who experienced an online course) toward online courses (including MOOCs). Therefore, in the second stage of the research, in parallel to the local online studies, students of two academic institutes were asked to complete a twenty-item questionnaire about their opinions regarding online courses.

The paper is organized as follows. First comes the theoretical review of MOOCs and local online courses upon which the study relies. Next, the research questions, the research methodology, and the local online course are described. Finally, the results are presented and discussed, and further research directions are suggested.

\section{Literature Review}

MOOCs (Massive Open Online Courses) are open to the public, free of charge, and without prerequisites. The lessons were initially asynchronous without academic credits. Over time, some of the MOOCs have become synchronous and some give academic credits subject to payment (Hativa, 2013; Spector, 2014). The MOOCs allow learning in a variety of fields from natural sciences and mathematics, social sciences including linguistics, and culture subjects. The MOOCs lasted several weeks (most of them from 4 to 17 weeks), and some thousands of students learn, from all over the world. The MOOCs rely on the cognitive-behaviouristic theory (Daniel, 2012; Rodriguez, 2012), and each week some lessons are given directly online by the course's instructor. Different kind of learning resources take advantage of these courses, including video clips, forums, assignments, quizzes, and final exams.

London relates to learning as a social process and the need for "connection" as a catalyst for learning. He argues: "The student who sits in a lecture hall with a hundred others rarely connects or interacts. He is as isolated as if he were alone. By contrast, an online student often has a mentor available from dawn to dusk. It is as if he is sitting on a metaphorical log with a tutor" (London, 2014, p.314).

The pedagogy in MOOCs often relies on a mix of 5-15 minutes of video lectures, reading materials, assignments to test understanding, and discussion groups that allow students to raise questions during the course. In many cases, questions are asked during the lectures, which test the students' comprehension of the issues discussed in the lecture. Usually, once a week, a large assignment is given to test deeper understanding of the studied subject matter. Many MOOCs allow learning towards mastery, meaning that the learner can take tests several times to improve his or her achievements (Pundak et. al., 2014).

Researchers and educators are dealing with quality evaluation in the MOOC. Some of them agree that the quality evaluation of distance learning is suitable to MOOCs. Shelton reviewed 13 studies of quality evaluation according the institution approach, and selected quality factors according to their ranking in the studies. The factor with the highest score (10 out of 13 studies) is the institution's commitment, and the next one is the teaching and learning approach (Shelton, 2011). The focus of this paper studies the learning experience in the online course, where we mainly discuss the quality of teaching and learning from two points of view: learners and instructors. 


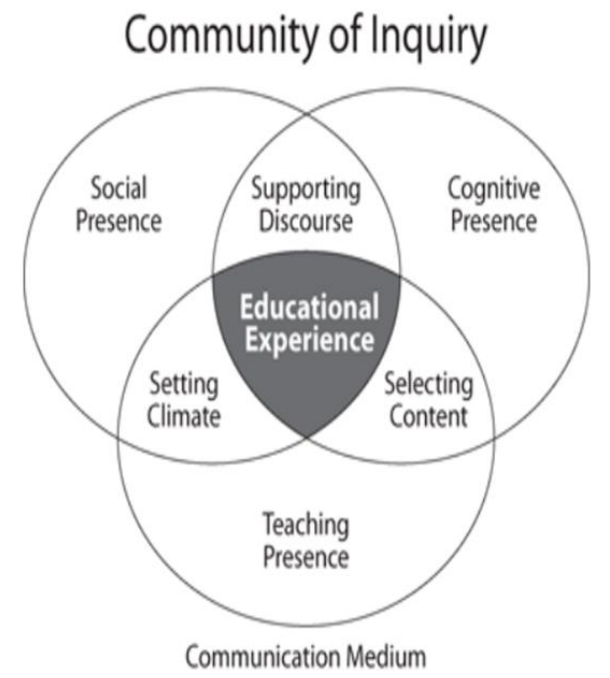

Figure 1. The theory of learning and teaching according Garrison (Garrison, 2000)

According Garrison, the Community of Inquiry (COI) represents a procedure for creating a deep and meaningful of learning experience (collaborative-constructivist) relying on three components: social presence, cognitive presence, and teaching presence (Garrison, 2000), as presented in Figure 1.

On the other hand, some researchers criticize the MOOC concept. Baggaley (2013) points out that many MOOCs are massive but not open, or open but not massive, or try very hard not to be courses. Sandeen (2013) asserts that there is only a 9-10 percent completion rate of most MOOCs and Wiener (2013) claims that one problem of the MOOCs trying to make money is that 90 percent of the people who enroll in courses do not complete them. Aguaded-Gómez (2013) argued against the quality of learning and the evaluation in MOOCs.

In a typical MOOC, the learners are an international audience, including some thousands of students. In comparison, a typical college online course at a single institution includes only dozens to hundreds of students. In many cases, some of the students know each other and meet one other on campus. Moreover, in the online courses the students communicate in their mother tongue and not in a foreign language, as happens for the vast majority of students in MOOCs. It is reasonable to assume that the social environment of online courses, in most cases, is friendlier for the learner compared to the MOOC.

Despite that, there are many common components to the online course and MOOCs. The researchers agree that the learners and both methods demand independent leaning, maturity, high discipline, high motivation, writing expression and communication, management of time and schedules, and orientation in the online environment (Leasure et. al., 2000; Conard \& Donaldson, 2012). The online students describe the reasons for their success as mutual learning, development of independent learning, and improvement of their computer skills (O'Neil \& Fisher, 2008).

The online environment allows both individual and cooperative learning supported by a variety of tools and methods such as synchronic teaching, audio and multimedia environments, forums, online assignments, video conferences, mutual editing environments, document sharing, and messages and blogs. These tools allow the application of various channels for learning and expression. The online courses reduce the tendency of the learner to depend upon the instructor as an information resource. The online learning methods emphasis the contribution of online tools with creating an environment of social interaction and constructivist learning (Beldarian, 2006; Downes, 2012).

For a non-native English speaker, a MOOC is a much more challenging learning environment compared with an online course at their own institution. The assumption of MOOC instructors that students will adjust themselves to the culture of their institution is not obvious for many learners. In addition, the social environment of MOOC is not familiar to a significant proportion of the learners. Besides the demand to learn new content, the students also must learn both the social environment and another institution's culture of teaching. In many cases, these challenges create a feeling of being "foreign students" that influences the students' behaviour during MOOC learning (Spector, 2014). The "foreign students" worry about requesting help or expressing their ideas at the forums. On the other hand, the 
online "native students" keep learning with well-known learning management systems (LMS), which in our case is Moodle. Moreover, many of the learning rules are already known from face to face (F2F) courses. For them, Moodle is the "native LMS" they are accustomed to using in all college courses. It seems that the "native students" will not hesitate to ask for help with difficulties or misunderstandings.

\section{Methodology}

\subsection{Research Questions}

The research objective was to answer the following questions:

1) What are the opinions of engineering students regarding local online courses compared to MOOCs?

2) What are the engineering students' expectations from the local online course about the history of science compared to their peers' expectations from MOOCs?

3) To what extent were the students satisfied with the local online courses and studying methods compared to MOOCs?

4) In which way does the forum of the online course contribute to the development of the students' argumentation?

\subsection{Population}

Several populations participated the research. First, eight engineering students finished MOOCs in the second semester of 2014 and the first semester of 2015. Then 25 students at an engineering college completed the local online course in 2015. Finally, 229 students from two colleges of engineering (the 8 MOOC students and the 25 online students are not included) answered a twenty-item opinions questionnaire. All the students were 23 to 28 years old.

\subsection{Research Tools}

Qualitative research tools were used to answer the research questions.

A twenty-item questionnaire concerning the students' opinion toward MOOCs and local online courses was composed and validated by three experts (according Flateby, (2016), one expert is sufficient). It was designed to aggregate students' opinions regarding five groups of subjects:

a. Informative data about the student's prior knowledge about online courses or MOOCs

b. The need for local online courses

c. The need for MOOCs

d. The chance of success in online courses or MOOCs

e. The MOOCs and online courses' characteristics

Deep open interviews were conducted with five students who participated in the local "History of Science" online course in 2015. The students' responses in the interviews were compared with responses given in the first stage of the research by students who took MOOCs in the second semester of the academic year 2014 and the first semester of 2015. One of the researchers observed the forum meetings of the History of Science course and ranked the quality of the students' argumentation without interacting in the ongoing sessions.

\subsection{Online Course Description}

The History of Science course describes the development of science through key scientists' impact, from the Greek philosophers through to the late medieval age. It starts with Darwin's theory of evolution, which is probably the most exciting example of scientific research. Darwin's theory evokes numerous questions on the contradiction between religious beliefs versus scientific facts. Therefore, it is an appropriate issue with which to start. The second group of subjects deals with the Greek philosophers Pythagoras, Socrates, and Plato; the universe according Aristo; Euclidean geometry and the measurement of distance; and Archimedes. The last group of subjects in the course deals with the decimal number system and the invention of zero; Middle Ages scientists Nicolaus Copernicus, Tycho Brahe, Johannes Kepler, Francis Bacon, and Galileo Galilei. The course scope is one semester of 14 weekly online lectures. The students can choose to watch the lectures on video and/or read the content on the course website.

The course assignments:

1) Submitting 13 homework exercises using the Web-assign platform

2) Participating in the course forum where every student is obligated to express an educated argument concerning the 
weekly issue of the course, at least eight times during the semester

3) Expressing a convincing reflection on at least one argument made by another student in the forum

4) A 25-multiple-choice final exam at the end of the semester

\section{Results}

\subsection{Engineering Students' Opinion of Local Online Courses and MOOCs}

Engineering students from two engineering colleges answered a Likert-style questionnaire. However, for simplicity of presentation, the percentage of agreement calculated for each item (except for item 1) is the sum of 4 and 5 answers (agree and strongly agree) divided by the number of students who answered the item. The percentage of non-agreement is calculated as the sum of 1 and 2 answers (disagree and strongly disagree) divided by the number of students who answered the item. Item one of the questionnaire is a yes or no question, therefore the percentage relates to the total number of students who answered 'yes' divided by the number of students who answered the item. The table in the appendix presents the detailed results for each of the questionnaire's items. However, Table 2 presents the students answers in an easy-to-read fashion by grouping them in five groups of subjects ('a' to 'e') as follows:

Group 'a' items deal with the students' prior knowledge. Even though 229 students answered the questionnaire, only $48 \%$ of the 114 who answered item 1 (Table 2) had prior experience with a Hebrew online course. Nevertheless, about $54 \%$ of the 186 who answered item 2 believe they know how an online course is managed.

Group ' $b$ ' items give an idea about the need for online courses from the students' point of view. To compress this information into one representative number, the weighted average percentage of agreement of all ' $b$ ' items (i.e., items $3,4,7,11,13$, and 14 in the appendix), was calculated as well as the average number of students who answered these items. This result indicates that there is a strong agreement between the students on the need for online courses. Note that item 11 is a negative phrase; therefore, the disagreement percentage was taken into the calculation.

Group 'c' and group 'd' results were calculated in the same manner as the group 'b' results. Group 'c' deals with the need for MOOCs (items 8 and 15 in the appendix). Group 'd' deals with the chance of success in the online courses and MOOCs (items 5, 6, and 10 in the appendix).

The results of the group 'c' items support the need for MOOCs according the students' opinions. The results of group 'd' point out that the students believe they can succeed in online courses and MOOCs as well as traditional courses. Note that item 10 is a negative expression; hence, the disagreement percentage was considered in the calculation.

Group 'e' includes items 9, 11, 12, 16, 17, 18, 19, and 20 of the questionnaire, and deals with the MOOCs' and online courses' characteristics. A quick look at the appendix shows that students' opinions toward most of the items is not decisive. Only item 9 showed student agreement: $58 \%$ of the students believe that the teacher-student relationship is better in a frontal course than in online courses and MOOCs (see the appendix).

Table 2. Students' responses to the twenty-item questionnaire, in five groups

\begin{tabular}{|c|c|c|c|c|}
\hline Group & Subject & Items & $\begin{array}{l}\text { Average no. of } \\
\text { respondents }\end{array}$ & $\%$ agreement \\
\hline a1 & I studied a Hebrew online course in the past & 1 & 114 & 48 \\
\hline $\mathrm{a} 2$ & I know how an online course is managed & 2 & 186 & 54 \\
\hline $\mathrm{b}$ & The need for local online courses & $\begin{array}{l}3,4,7,11,13, \\
14\end{array}$ & 213 & 60 \\
\hline $\mathrm{c}$ & The need for MOOCs & 8,15 & 217 & 55 \\
\hline $\mathrm{d}$ & $\begin{array}{l}\text { The chance of success in online course or } \\
\text { MOOCs }\end{array}$ & $5,6,10$ & 215 & 54 \\
\hline $\mathrm{e}$ & $\begin{array}{l}\text { The MOOCs' and online courses' } \\
\text { characteristics }\end{array}$ & $\begin{array}{l}9,11,12,16,17 \\
18,19,20\end{array}$ & 199 & not decisive \\
\hline
\end{tabular}




\subsection{Students' Expectations from Local Online Courses Compared to MOOCs}

The second research question is about the students' expectations from online courses, including local online courses and MOOCs. The first stage of the current research (author, 2014) investigates students' expectations and considerations when choosing MOOCs, while the second stage deals with the students' expectations and considerations regarding the local online course.

Interviews with students of the first stage revealed that the most important criteria for choosing MOOCs are the interest stimulated by the course content and the opportunity to study a fascinating subject; the course lecturers' characteristics, their personalities and the unique knowledge that they present; and the opportunity to gain deeper knowledge of a subject they already know. An additional reason for their choice was the connection between the course content and their hobby (author, 2014).

The second stage revealed that the most important criterion for choosing the local online course, which is one of the general studies courses, is the students' convenience and the suitability to their schedule. All five interviewees are in their final semester of studying and need to take one last general course. Here is a typical citation of a student.

S1: This is my final semester toward the BSc. I must take one general studies course.

The students are all working at this stage of their studies, and some of them are married with a baby. Therefore, they looked for a course to study without attending the classroom, as argued by student S3 in her interview:

S3: I am working and I have a daughter. I looked for a convenient option of study hours. It helps me that I don't have to come to the college.

Only one of the interviewees (S2) argued: I am interested in the history of science. I did not choose it because it is an online course.

Their other expectations were to invest roughly two to three weekly hours and that the course material would not be too difficult. The students' considerations, frequencies, and typical quotes are presented in Table 3. Table 3 also presents the relevant expectations of the MOOC students for comparison (author, 2014).

Table 3. Students' preferences and expectations regarding the local online course vs. MOOCs

\begin{tabular}{|c|c|c|c|}
\hline Issue & Population & Student's argument & Typical quote \\
\hline \multirow{5}{*}{$\begin{array}{lr}\text { Why did you } \\
\text { choose } & \text { the } \\
\text { course? } & \end{array}$} & \multirow{3}{*}{$\begin{array}{l}\text { Online } \\
\text { course } \\
\text { students }\end{array}$} & Final semester & $\begin{array}{l}\text { This is my final semester toward the BSc. I } \\
\text { must take one general studies course. }\end{array}$ \\
\hline & & $\begin{array}{l}\text { My schedule convenience } \\
\text { as a working person }\end{array}$ & $\begin{array}{l}\text { I looked for something that will allow time } \\
\text { flexibility. I am working and have a newly born } \\
\text { child. }\end{array}$ \\
\hline & & Interesting subject & $\begin{array}{l}\text { I am interested in the history of science. I did } \\
\text { not choose it because it is an online course. }\end{array}$ \\
\hline & \multirow[t]{2}{*}{$\begin{array}{l}\text { MOOCs } \\
\text { students }\end{array}$} & $\begin{array}{l}\text { Interest in the course } \\
\text { content, and the } \\
\text { opportunity to study a } \\
\text { fascinating subject }\end{array}$ & $\begin{array}{l}\text { I read about the subject, so I expect to reach a } \\
\text { deep understanding and to enjoy the course. }\end{array}$ \\
\hline & & $\begin{array}{l}\text { Lecturers' profile and the } \\
\text { unique knowledge they } \\
\text { present. }\end{array}$ & $\begin{array}{l}\text { The privilege to learn from Dan Arieli (Ig Nobel } \\
\text { laureate) is my personal dream. }\end{array}$ \\
\hline \multirow{4}{*}{$\begin{array}{l}\text { What were your } \\
\text { expectations } \\
\text { from the } \\
\text { course? }\end{array}$} & \multirow{2}{*}{$\begin{array}{l}\text { Online } \\
\text { course } \\
\text { students }\end{array}$} & Easy subject matter & $\begin{array}{l}\text { I must deal with my final project and with the } \\
\text { time I spend in my workplace. }\end{array}$ \\
\hline & & $\begin{array}{l}\text { That it will be interesting } \\
\text { for me }\end{array}$ & $\begin{array}{l}\text { I liked the idea of expressing my own opinion in } \\
\text { the forum. }\end{array}$ \\
\hline & \multirow[t]{2}{*}{$\begin{array}{l}\text { MOOCs } \\
\text { students }\end{array}$} & $\begin{array}{l}\text { Attain deeper } \\
\text { understanding of the } \\
\text { studied subjects }\end{array}$ & $\begin{array}{l}\text { I expect to know more about the world (The } \\
\text { course called "Imagining Other Earths") }\end{array}$ \\
\hline & & opportunity & I wanted to acquire knowledge in "Forensic \\
\hline
\end{tabular}




\begin{tabular}{|c|c|c|c|}
\hline & & $\begin{array}{l}\text { reinforce professional } \\
\text { background }\end{array}$ & $\begin{array}{l}\text { Science", to widen my horizons and it might } \\
\text { help me in the "startup" direction. }\end{array}$ \\
\hline $\begin{array}{lr}\text { How } & \text { many } \\
\text { weekly } & \text { hours } \\
\text { did you } & \text { expect }\end{array}$ & $\begin{array}{l}\text { Online } \\
\text { course } \\
\text { students }\end{array}$ & 2-3 hours a week & $\begin{array}{l}\text { The normal time spent on general courses is } \\
\text { about two hours a week. }\end{array}$ \\
\hline $\begin{array}{l}\text { to spend on the } \\
\text { course? }\end{array}$ & $\begin{array}{l}\text { MOOCs } \\
\text { students }\end{array}$ & Up to 6-7 hours a week & $\begin{array}{l}\text { I intend to spend about six to seven hours a } \\
\text { week on watching the lectures and writing } \\
\text { homework. }\end{array}$ \\
\hline
\end{tabular}

\subsection{Students' Satisfaction with Course Content and Methods}

Interviews were conducted toward the end of the online course, so the students had sufficient time to form their own ideas about the course content and its learning methods. Concerning the content, the students were divided in their opinions; some liked it and others disliked it. Most of the students were for integrating the forums and argued that they learn a lot from them. The students were also for the use of automatic assignment testing (the Web-assign platform). The students' opinions are presented in Table 4 . Table 4 also presents the MOOCs students' satisfaction, as mentioned in (author, 2014), for comparison.

Table 4. Students' satisfaction with course content and learning methods

\begin{tabular}{|c|c|c|c|}
\hline Issue & Group & Student's argument & Typical quote \\
\hline \multirow{3}{*}{$\begin{array}{l}\text { How interesting } \\
\text { are the contents } \\
\text { of the course? }\end{array}$} & \multirow{2}{*}{$\begin{array}{l}\text { Online } \\
\text { course } \\
\text { students }\end{array}$} & Very interesting & $\begin{array}{l}\text { The course showed me the history of science in a new } \\
\text { light. I am interested in this subject. }\end{array}$ \\
\hline & & Less interesting & $\begin{array}{l}\text { To tell you the truth, the subject is not so interesting to } \\
\text { me. }\end{array}$ \\
\hline & $\begin{array}{l}\text { MOOCs } \\
\text { students }\end{array}$ & $\begin{array}{l}\text { Very interesting } \\
\text { lecturer and content }\end{array}$ & $\begin{array}{l}\text { The reason for my great investment is the lecturer's } \\
\text { personality and how he runs the course. I also hope that } \\
\text { this course will help me fulfill my dream to be an } \\
\text { organizational advisor. }\end{array}$ \\
\hline \multirow{3}{*}{$\begin{array}{l}\text { What do you } \\
\text { like and what } \\
\text { do you dislike } \\
\text { about the }\end{array}$} & \multirow{2}{*}{$\begin{array}{l}\text { Online } \\
\text { course } \\
\text { students }\end{array}$} & Very good & $\begin{array}{l}\text { The conversations in the forum are very civilized. I } \\
\text { learned a lot from the forums. }\end{array}$ \\
\hline & & Less good & $\begin{array}{l}\text { Occasionally, some students have nothing to say, so } \\
\text { they say something just to fulfil their obligations. }\end{array}$ \\
\hline & $\begin{array}{l}\text { MOOCs } \\
\text { students }\end{array}$ & Avoided the forum & $\begin{array}{l}\text { I am not in the forum. I have too many courses to learn, } \\
\text { I have no time. }\end{array}$ \\
\hline \multirow{3}{*}{$\begin{array}{l}\text { What do you } \\
\text { think about the } \\
\text { assignments } \\
\text { tester } \\
\text { (Web-assign)? }\end{array}$} & \multirow{2}{*}{$\begin{array}{l}\text { Online } \\
\text { course } \\
\text { students }\end{array}$} & $\begin{array}{l}\text { It contributes to } \\
\text { meaningful learning }\end{array}$ & $\begin{array}{l}\text { The immediate feedback reinforces my learning. Doing } \\
\text { the assignment while learning helps me memorize. }\end{array}$ \\
\hline & & $\begin{array}{l}\text { The assignments are at } \\
\text { a routine level }\end{array}$ & $\begin{array}{l}\text { Many of the assignments are shallow and do not need a } \\
\text { deep understanding. }\end{array}$ \\
\hline & $\begin{array}{l}\text { MOOCs } \\
\text { students }\end{array}$ & $\begin{array}{l}\text { There was no use of } \\
\text { web-assign }\end{array}$ & \\
\hline
\end{tabular}

\subsection{Online Course Forum}

To monitor the students' activity in the forum, one of the researchers participated in eight sessions during the course as a silent observer. She ranked the students' original arguments and the students' criticism toward their friends' arguments on a scale of 1-3, where 1 is a shallow argument and 3 is an educated argument. The results in Table 5 show that at the beginning of the course the students raised shallow original arguments and critical arguments. The argumentation level slightly improved toward the middle of the course, and then lowered again toward the end of the course. However, it can be noted that the level of critical arguments is lower than the level of original arguments. 
Table 5. Level of students' arguments and criticism in the forum

\begin{tabular}{lllll}
\hline Week no. & $\begin{array}{l}\text { No. of original } \\
\text { arguments }\end{array}$ & $\begin{array}{l}\text { Average level of original } \\
\text { arguments on a scale of } \\
1-3\end{array}$ & $\begin{array}{l}\text { No. of criticism } \\
\text { arguments }\end{array}$ & $\begin{array}{l}\text { Average level of criticism } \\
\text { arguments on a scale of } \\
1-3\end{array}$ \\
\hline 1 & 5 & 2.40 & 9 & 1.89 \\
2 & 1 & 3.00 & 0 & \\
3 & 3 & 2.33 & 7 & 1.64 \\
5 & 3 & 2.67 & 6 & 2.25 \\
8 & 10 & 2.50 & 5 & 2.20 \\
9 & 5 & 2.30 & 6 & 1.67 \\
10 & 4 & 2.38 & 11 & 2.00 \\
11 & 5 & 2.50 & 9 & 1.61 \\
Weighted & & 2.46 & & 1.88 \\
average & & & & \\
\hline
\end{tabular}

Regarding the contribution of the online course forums to the development of the students' argumentation, some interesting findings were collected through the interviews. The next two quotations speak for themselves:

Student 1: "I have to say that the course is very interesting and every time it causes me to reconsider lots of questions and scientific doubts."

Student 2 presented an example of a case that caused a change in the student's thinking: "Some of them (students in the forum) related to Hitler and Stalin as leaders; it was a shocking idea that forced me to think that a leader is not necessarily a good person."

\section{Discussion}

The first research question deals with the students' opinion regarding local online courses and the need for MOOCs. The results in Table 2 show that only $48 \%$ of the 114 who answered item 1 (i.e., $24 \%$ of the 229 students who answered the questionnaire) had prior experience with a Hebrew online course. Nevertheless, about $54 \%$ believe they know how an online course is managed. Most of the students' answers, with a relatively high score of agreement, belong to groups ' $b$ ' and ' $c$ ', which refer to the need for local online courses and MOOCs. Thus, most of the students believe that the experience with online course is important $(60 \%$ for the need for online courses and $55 \%$ for MOOCs), and that college students should learn at least one online course during their college studies (58\% agree versus $20 \%$ disagree). They think that in their future engineering practice they will need to study various subjects in an online way (76\% agree versus $9 \%$ disagree). Therefore, they want to try to learn in online courses and think that the college should integrate MOOCs developed by world leading universities in its study programs (54\% agree versus $20 \%$ disagree). As expected, more students prefer to study online courses in their mother tongue than MOOCs in English (68\% agree with item 13 and 49\% with item 14). About 54\% of the students believe they can succeed in online courses and MOOCs as well as traditional courses.

No significant agreement was found between the students concerning the MOOCs' and online courses' characteristics. The explanation for this might be the fact that most of students who answered the questionnaire have no prior experience with online learning; therefore, they have no unified opinion about different aspects of online courses. Nevertheless, the students reached agreement on item 9; about 58\% of the students believe that the teacher-student relationship is better in frontal courses than in online courses (including MOOC).

The second research question concerned the engineering students' expectations from the local online course compared to their peers' expectations from MOOCs. Regarding the students' considerations when choosing the online course, the MOOC students put these items as their main considerations: their interest in the course content, the opportunity to study a fascinating subject, and the lecturers' unique profiles. They expected to attain a deeper understanding of the studied subjects and reinforce professional background. They also expected to spend 6-7 hours a week studying the course. On the other hand, the local online students preferred schedule convenience and their interest in the course content. They hoped the course subject would be easy and interesting for them and they also expected to spend 2-3 hours a week studying the course. 
The third research question is about the students' satisfaction with the content of the local online course and its studying methods in comparison to MOOCs. Concerning the content, all the MOOC students described the content (and the lecturers) as very interesting while the online students were divided in their opinions; only some liked the content. Regarding the contribution of the forum to the course, all the MOOC students avoided the forums while the online students were obligated to participate in the forums, which most of them liked, reporting that they learned a lot from it even though some found it banal. On the other hand, all the MOOC students avoided participating in the forums and did not use any automatic assignments tester, unlike the online students who liked the automatic assignments tester (Web-assign), believing it contributed meaningfully to their learning.

The last research question relates to the contribution of the forum in the local online course-History of Science- to the development of the students' argumentation. The results in Table 5 show that at the beginning of the course the students raised shallow arguments. During the course, the argumentation level slightly improved. The second row of Table 5 is an exception but it is only relates to one case and therefore can be ignored. However, the level of critical argumentation is lower than the level of original arguments; moreover, the critical arguments are at low level at the beginning of the course, improve toward the middle part of the course, and then get worse towards the end of the course. This can be explained by the fact that the students became tired and had less time to invest in deep arguments toward the end of the course.

\section{Conclusions}

The analysis of students' answers to the twenty-item questionnaire, which refers to their beliefs and preferences about learning online courses or MOOCs, reveals that most engineering students think that online studying is important and they want to undergo online learning. There is strong support for the integration of local online courses and MOOCs, with priority to the local online courses. Most of the students believe that they will need to study online course in their professional life. The participation of 25 students in the online course in comparison with eight students in the MOOCs in two successive semesters also expresses a significant preference for the online course over the MOOCs. These results match the theory of learning and teaching according Garrison (2000). The learners' expectations are better suited to the three domains (social, cognitive and teaching community inquiry) in a local online course compared to MOOCs.

The MOOC students are more interested in the subject of the course than the local online course students are. This finding is not surprising since the first criterion for choosing the MOOCs was its interest for the students. The most important criterion for the online course participation was the students' convenience.

The course forum has a positive impact on the students' satisfaction, the students' argumentation and criticism and in some cases, makes a change in the students' way of thinking. The forum has an important role in the course as a lively stage for discussion and interaction between the students, and between the instructor and the students. High involvement of all the participants could contribute to satisfaction and a higher level of learning.

\section{References}

Aguaded-Gómez, J. I. (2013). The MOOC Revolution: A new form of education from the technological paradigm. Comunicar, 4l(21), (pp. 07-08). Retrieved from https://www.revistacomunicar.com/pdf/comunicar44-en.pdf

Baggaley, J. (2013). MOOC rampant. Distance Education, 34(3), 368-378. http://dx.doi.org/10.1080/01587919.2013.835768

Beldarian, Y. (2006). Distance education trends: Integrating new technologies to foster student interaction and collaboration. Distance Education, 27(2), 139-153. Retrieved from https://mhspa.wikispaces.com/file/view/EDLD5362_Distance+Education+Trends.pdf

Conard, R. M., \& Donaldson, J. A. (2012). Continuing to Engage the Online Learner: More Activities and Resources for Creative Instruction. Jossey-Bass. A Wiley Imprint.

Daniel, J. (2012). Making sense of MOOCs: Musings in a maze of myth, paradox and possibility. Journal of Interactive Media in Education. Retrieved from http://jime.open.ac.uk/article/10.5334/2012-18/

Downes, S. (2012). Connectivism and Connective Knowledge: Essays on meaning and learning networks. Retrieved from http://www.downes.ca/files/Connective_Knowledge-19May2012.pdf

Flateby, T. L. (2016). A guide for writing and improving achievement tests. Univ. of South Florida., 2016, October 1. Retrieved

from https://www.yumpu.com/en/document/view/24204592/a-guide-for-writing-and-improving-achievement-tests-ge orgia- 
Garrison, D. R., Anderson, T., \& Archer, W. (2000). Critical thinking in text-based environment: Computer conferencing in higher education. The Internet and Higher Education, 2(2), 87-105. https://doi.org/10.1016/S1096-7516(00)00016-6

Hativa, N. (2013). The tsunami of MOOCs: Will it cause a revolution in teaching, learning and the higher education institutions? An overview. Teaching in the Academia, 1, 40-64. [Hebrew]

Leasure, A. R., Davis, L., \& Thievon, S. L. (2000). Comparison of student outcomes and preferences in a traditional vs. world wide Web-based baccalaureate nursing research course. Journal of Nursing Education, 39(4), 149-154.

London, H. I. (2014). MOOCs on the March. Academic Questions, 27(3), 313-315. https://doi.org/10.1007/s12129-014-9432

O'Neil, C., \& Fisher, C. (2008). Should I take this course online? Journal of Nursing Education, 47(2), 53-59.

Pundak, D., Sabag, N., \& Trotskovsky, E. (2014). Accreditation of MOOCS. European Journal of Open, Distance and E-Learning, 16(2), 116-128.

Rodriguez, C. O. (2012). MOOCs and the AI-Stanford like courses: Two successful and distinct course formats for massive open online courses. European Journal of Open, Distance and E-learning, (1). Retrieved from http://www.eurodl.org/?article=516

Sandeen, C. (2013). Integrating MOOCs into traditional higher education: The emerging "MOOC 3.0" era, Change, 34-39. http://dx.doi.org/10.1080/00091383.2013.842103

Shelton, Kaye. (2011). A Review of Paradigms for Evaluating the Quality of Online Education Programs. Online Journal of Distance Learning Administration, 4(1). Retrieved from http://wp.westga.edu/wp-content/uploads/sites/40/ojdla/spring141/shelton141.pdf

Spector, J. M. (2014). Remarks on MOOCs and Mini-MOOCs. Educational Technology Research and Development, 62(3), 385-392. https://doi.org/10.1007/s11423-014-9339-4

Wiener, J. (2013). Inside the Coursera Hype Machine. The Nation, 17-21. 


\section{Appendix. Detailed students' responses to the twenty-item questionnaire}

\begin{tabular}{|c|c|c|c|c|}
\hline No. & Item & $\begin{array}{l}\text { No. of } \\
\text { responses }\end{array}$ & $\%$ & $\begin{array}{c}\% \\
\text { disagree }\end{array}$ \\
\hline 1 & I studied a Hebrew online course in the past. & 114 & 48 & 52 \\
\hline 2 & I know how an online course is managed. & 186 & 54 & 31 \\
\hline 3 & $\begin{array}{l}\text { College students should learn at least one online course during their } \\
\text { college studies. }\end{array}$ & 215 & 58 & 20 \\
\hline 4 & $\begin{array}{l}\text { In my work as an engineer, after graduation, I will need to study } \\
\text { various subjects online. }\end{array}$ & 210 & 76 & 9 \\
\hline 5 & One can succeed in learning online courses as regular course study. & 221 & 61 & 21 \\
\hline 6 & $\begin{array}{l}\text { The study material that appears on the course site helps in } \\
\text { understanding the topics taught. }\end{array}$ & 204 & 58 & 23 \\
\hline 7 & $\begin{array}{l}\text { The college should integrate local online courses, developed by Israeli } \\
\text { universities, in its study programs. }\end{array}$ & 220 & 67 & 13 \\
\hline 8 & $\begin{array}{l}\text { The college should integrate MOOCs developed by world leading } \\
\text { universities in its study programs. }\end{array}$ & 218 & 54 & 23 \\
\hline 9 & $\begin{array}{l}\text { The student-lecturer relationship in a frontal course is better than in an } \\
\text { online course. }\end{array}$ & 219 & 58 & 23 \\
\hline 10 & $\begin{array}{l}\text { I think it would be hard for me to learn in an online course because it } \\
\text { requires higher self-discipline compared to a standard class. }\end{array}$ & 219 & 34 & 44 \\
\hline 11 & I prefer to graduate without learning in online courses. & 200 & 31 & 39 \\
\hline 12 & $\begin{array}{l}\text { The learning outcomes of an online course are better than those of a } \\
\text { frontal course. }\end{array}$ & 194 & 29 & 35 \\
\hline 13 & $\begin{array}{l}\text { It is suggested that the college will offer more online courses to the } \\
\text { students. }\end{array}$ & 222 & 68 & 12 \\
\hline 14 & $\begin{array}{l}\text { I would register to an interesting online course in English if the } \\
\text { college suggests such courses. }\end{array}$ & 212 & 49 & 29 \\
\hline 15 & $\begin{array}{l}\text { I would register to an interesting MOOC in English, administrated by } \\
\text { a world leading university, if the college suggests such courses. }\end{array}$ & 216 & 56 & 23 \\
\hline 16 & $\begin{array}{l}\text { Online course requirements are generally higher than standard course } \\
\text { requirements. }\end{array}$ & 181 & 29 & 26 \\
\hline 17 & $\begin{array}{l}\text { Studying time devoted to an online course is greater than the time } \\
\text { devoted to a similar frontal course. }\end{array}$ & 207 & 39 & 31 \\
\hline 18 & Studying in an online course is very interesting. & 196 & 36 & 20 \\
\hline 19 & $\begin{array}{l}\text { An online course allows me more meaningful study than a regular } \\
\text { course. }\end{array}$ & 201 & 32 & 34 \\
\hline 20 & Studying in an online course is more exciting than a regular course. & 196 & 34 & 40 \\
\hline
\end{tabular}

